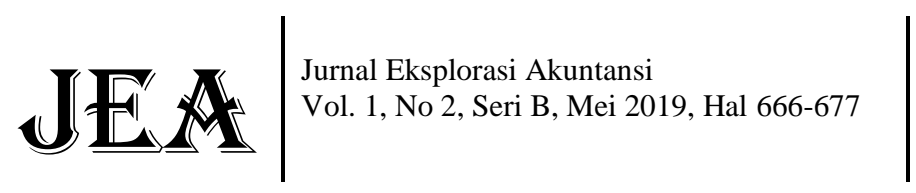

ISSN : 2656-3649 (Online)

http://jea.ppj.unp.ac.id/index.php/jea/issue/view/6

\title{
PENGARUH PARTISIPASI ANGGARAN TERHADAP BUDGETARY SLACK DENGAN PSYCHOLOGICAL CAPITAL SEBAGAI VARIABEL PEMODERASI
}

\author{
(Studi Empiris Pada Universitas Bung Hatta)
}

\author{
Tiwi Maitri Arista ${ }^{1}$, Efrizal Syofyan ${ }^{2}$ \\ ${ }^{1)}$ Alumni Jurusan Akuntansi Fakultas Ekonomi Universitas Negeri Padang \\ 2)Jurusan Akuntansi Fakultas Ekonomi Universitas Negeri Padang \\ *Korespondensi: tiwimaitri05@gmail.com
}

\begin{abstract}
The purpose of this research is to discover how the influence impact of budgetary participation on budgetary slack with psychological capital as a moderating variabel in structural leader and budget team, who are directly involved and have responsibilities for budgeting process in their fields and devises to solve the research problem. There for analysis used is a moderated regression analysis moderated regression analysis (MRA), the result shows that budgeting participation will improve and have a significant positive effect on budgetary slack in uncertainty and unexpected events while preparation and implementation of budgets at Bung Hatta University who was strengthened by psychological capital, which is a moderation in the relationship between budget, participation and budgetary slack.
\end{abstract}

Keywords: Budgetary Participation; Budgetary Slack; Psychological Capital

How to cite (APA $6^{\text {th }}$ style)

Arista, T. M \& Syofyan, E. (2019). Pengaruh Partisipasi Anggaran Terhadap Budgetary Slack Dengan Psychological Capital Sebagai Variabel Pemoderasi (Studi Empiris Pada Universitas Bung Hatta). Jurnal Eksplorasi Akuntansi, 1(2), Seri B, 666-677.

\section{PENDAHULUAN}

Di dalam sebuah organisasi baik itu pemerintahan maupun swasta anggaran memegang peran penting sebagai alat manajemen untuk mengendalikan operasi perusahaan agar strategi yang di tetapkan dapat digunakan untuk mencapai tujuan suatu perusahaaan. dan anggaran juga merupakan alat pengendalian agar manajer dapat melaksanakan kegiatan organisasi secara lebih efektif dan efisien Ikhsan (2007:2). Serta anggaran dapat berfungsi sebagai alat pengendalian jika dalam penyusunannya melibatkan pihak-pihak yang terlibat dalam pelaksanaan anggaran. Pihak-pihak yang dimaksud adalah atasan (principal) dan bawahan (agent). Banyaknya kepentingan dalam anggaran menyebabkan proses penganggaran akan sangat rentan terhadap berbagai bentuk penyimpangan baik dalam bentuk perilaku opportunistik maupun moral hazard dari pihak-pihak yang terkait didalamnya (Romarina, 2010). 
Penyusunan anggaran di Universitas Bung Hatta mempunyai alur kebijakan yang sistematis dan terkoordinir melalui pendekatan bottom up yang melibatkan pejabat struktural tingkat bawah sampai dengan pejabat struktural tingkat atas. Pendekatan bottom up memungkinkan terjadinya negosiasi antara Pimpinan Universitas sebagai operasional pengguna anggaran dengan Badan Pengurus Yayasan Pendidikan Bung Hatta sebagai pengawas opersional anggaran untuk mencapai tujuan organisasi.

Senjangan anggaran adalah hal yang disengaja dengan menurunkan target kinerja dan meningkatkan konsumsi sumber daya agar mudah diselesaikan sehingga pada saat evaluasi kinerja mereka terlihat produktif atas anggaran yang telah mereka susun (Damrongsukniwat, 2015). Pada saat staf bawahan memberikan perkiraan yang tidak jelas kepada atasan atau pimpinan, timbul senjangan anggaran (budgetary slack). Beberapa peneliti akuntansi menemukan bahwa tingkat senjangan anggaran dipengaruhi oleh beberapa faktor termasuk besarnya peran atau partisipasi staf bawahan didalam membuat dan meyusun anggaran.

Salah satu faktor yang menyebabkan terjadinya budgetaryslack yaitu partisipaasi anggaran. Nurrasyid (2015) berpendapat bahwa partisipasi penyusunan erat hubungannya dengan seberapa jauh keterlibatan dan pengaruh individu dalam proses penyusunan anggaran dengan adanya partisipasi anggaran maka dapat terjadi keselarasan tujuan suatuorganisasi. Apabila dikaitkan dengan teori keagenan, partisipasi anggaran merupakan proses kerjasama antara manajer tingkat bawah selaku ageen dan manajer tingkat atas selakuprinsipal dalam pengambilan keputusan yang berkaitan dengan penganggaran.

Dengan semakin berkembangnya penelitian mengenai partisipaasi anggaran dan budgetary slack maka penelitian ini digunakan variabel moderasi yang terbilang masih baru yang dapat dikaitkan dengan budgetary slack dengan menammbahakan variabel yang di diduga dapat mempengaruhui keduanya seperti faktor psikologi dapat berupaya mempengaruhi terjadinya senjangan anggaran. Bila berlebihan anggaran terlalu besar seluruh rencana perlu diawasi, untuk menghasilkan sebuah anggaran yang efektif manajer disuatu perusahaan membutuhkan kemampuan untuk mempridiksi masa depan, dengan mempertimbangkan beberapa faktor seperti faktor lingkungan, dan kondisi psikis. Kondisii psikis itu sendiri disebut psychological capital yang dapat diartikan sebagai modal psikologiis atau semacam modal sikap dan prilaku manusia yang berperan besar dalam menentukan keberhasialan suatu organisasi (Luthans, et al 2008).

Pentingnya penelitian ini untuk dilakukan agar dapat mengetahui bagaimana pengaruh partisipasi anggaran terhadap budgetary slackdi lingkungan universitas bung hatta, dan Untuk mengetahui bagaimana pengaruh partisipasi anggaranterhadap budgetary slack dengan psychological capital sebagai variabel moderasi pada Universitas Bung Hatta.Penelitian ini ingin mengkonfirmasi dan melanjutkan dari hasil penelitian Yuni asturi (2018) tentang pengaruh partisipasi anggaran terhadap budgetary slack dengan psychological capital sebagai variabel intervening yang diteliti di rumah sakit Jayapura.

\section{REVIEW LITERATUR DAN HIPOTESIS \\ Teori Keagenan (Agency Theory)}

Teori keagenan adalah teori yang menjelaskan hubungan prinsipal dan agen ini salah satunya berakar pada teori ekonomi, teori keputusan, sosiologi, dan teori organisasi. Menurut Anthony dan Govindarajan (2005:269). Hubungan agensi muncul ketika salah satu pihak (prinsipal) menyewa pihak lain (agen) untuk melaksanakan suatu jasa, dimana principal mendelegasikan wewenang kepada agen untuk membuat keputusan. 


\section{Teori Atribusi (Attribution theory)}

Teori atribusii menjelaskan bahwa perilaku indiviidu ditentukan oleh kekuatan faktor internal atau yang berasal dari dalamdiri dan kekuatan faktor eksternal atau dari luar (Ikhsan dan Ishak, 2005:55). Teori atribusi dalam penyusunan anggaran, dapat menentukan arah individu dalam menyusun anggaran dimana ketika cenderung berperilaku positif maka individu akan berusaha menghindari senjangan anggaran, sedangkan bila cenderung berperilaku negatif maka individu akan melakukan segala cara untuk mencapai tujuan kemudian akan melakukan senjangan anggaran (Firmansyah dkk, 2017).

\section{Anggaran}

Anggaran adalah sebuah rencaana kerja yang dinyataakan secara kuanttitatif dan diukur dalam satuan moneter standar. Satuan ukuran lainnya yang digunakan dalam anggaran adalah jangka waktu, yaitu dalam satu tahun (Mulyadi, 2011). Anggaran sering kali digunakan untuk mengukur atau menilai kinerja aktual para atasan dan bawahan sehingga anggaran berpengaaruh besar terhadap periilaku atasan dan bawahan (Putranto,2012). Anggaran (budget) merupakan renacana tertulis mengenai kegiatan suatuorganisasi yang dinyatakan dalam suatu uang, tetapi dapat juga dinyataakan dalam satuan barang/jasa. Disatu sisi anggaran merupakan salah satu komponen penting dalam sebuah organisasi, dimana anggaran berperan sebagai alat untuk perenncanaan dan disisii lain anggaran digunakan sebagai alat pengendalian jalannya operasi perusahaan agar strategi yang ditetapkan dapat digunakan untuk mencapai tujuan suatu perusaaahaan atau instansi yang terkait.

\section{Partisipasi Anggaran}

Partisipasi penganggaran mempunyai arti penting sebab anggaran berfungsi sebagai motivasi bawahan dengan memberikan target untuk mencapai tujuan (Tanaya \& Krisnadewi 2016). partisipasi anggaran adalah proses yang menggambarkan individu terlibat dalam penyusunan anggaran dan mempunyai pengaruhterhadap target anggaran dan perlunya penghargan atas pencapian target anggaran tersebut, Sedangkan menurut Dinni (2009) partisipasi anggaran adalah suatu proses dalam organisasi yang melibatkan para manaajer dalam penentuan tujuan anggaaran yang menjadi tanggung jawabnya. Partisipaasi anggaran dapat dikatakan proses dimana pihakpihak tertentu terlibat dalam proses penyusunan anggaran dan berpengaruh dalam penetapan anggaran itu sendiri.

\section{Senjangan anggaran (Budgetary Slack)}

Budgetary slack adalah suatu tindakan dimana agen melebiihi kemampuan produktiif dengan mengistimasikan pendapatan lebihrendah dan biaya lebih tinggi ketikaa disuruh memlih standar kerja agar anggaran yang sudah buat dapat terealisasi.

\section{Model Psikologis (Psychological Capital)}

Kondisii psikis itu sendiri disebut sebagai psychological caapital (Abineri 2016). Psycap is founded in postife psychology and focuses" on the "development of individuals strengths rathers thans focusing" in postive psychology and" focuses on the developmeent of individuals strengths rather than focusing on indentifying their weaknesses (Venkatesh, 2014.)". 


\section{Pengaruh Partisipasi Anggaran Terhadap Budgetary Slack}

Dengan keterlibatan bawahan dalam penyusunan anggaran, tindakan disfungsional tidak dapat terhindarkan karena partisipasi atasan menjadi berkurang dan bawahan dapat dengan mudah bermain dalam sistem anggaran. Dengan keikutsertaan manajer tingkat bawah dalam penetapan anggaran akan menambah jumlah orang yang terlibat dan senjangan anggaran akan semakin tinggi. Sesuai dengan penelitian Basyir (2016) partisipasi anggaran berpengaruh positif terhadap budgetary slack.

Hasil Penelitian yang dilakukan Sancita (2014) menunjukan partispasi anggaran berpengaruh signiifikan terhadap Budgetary Slack yang menunjukkan variabel partisipasi anggaran berpengaruh positif terhadap senjangan anggaran dengan penelitian (NiMade:2016) yang menyatakan partisipasi penganggaran berppengaruh pada senjangan anggaran di Universitas Udayana. Berbeda dengan penelitan lain mengatakan bahwa partisipaasi anggaran dan senjangaan anggaran mempunyai hubungan negatiif, semakin tinggi partisipasi dalam anggaran, semakin kecil senjangan anggaran. Yosfan Yunas (2013) bahwa variabel partisipasi anggaran tidak signifikan / tidak mempunyai pengaruh terhadap senjangan anggaran"

$\mathrm{H}_{1}$ : Partisipasi anggaran berpengaruh positif terhadap Budgetary Slack.

\section{Pengaruh Partisipasi Anggaran Terhadap Budgetary Slack Dengan Psychological Capital Sebagai Variabel Moderasi.}

Semakin tinggi tingkat keterlibatan bawahan dalam proses penyusunan anggaran maka pegawai tersebut akan memiliki perilaku psikologis yang positif yang pada akhirnya dapat meningkatkan kinerjanya. Selanjutnya, semakin tinggi tingkat partisipasi anggaran juga semakin signifikan tingkat budgetary slack dimana prilaku modal psikis individu memoderasi pengaruh partispasi anggaran dimana tingginya tanggung jawab yang dimiliki individu akan mengurangi budgetary slack. Dimana kepentingan psikis yang kuatt yang lebih mengutamakan kepentingan pribadi seseorang dapat melakukan senjangan anggaran lebih mudah dicapai dan pada akhirnya keberhasilan sasaran anggaran mudah diharapkan".

$\mathrm{H}_{2}$ : Partisipasi anggaran berpengaruh terhadap budgetary slack dengan Psychological capital sebagai variabel memoderasi

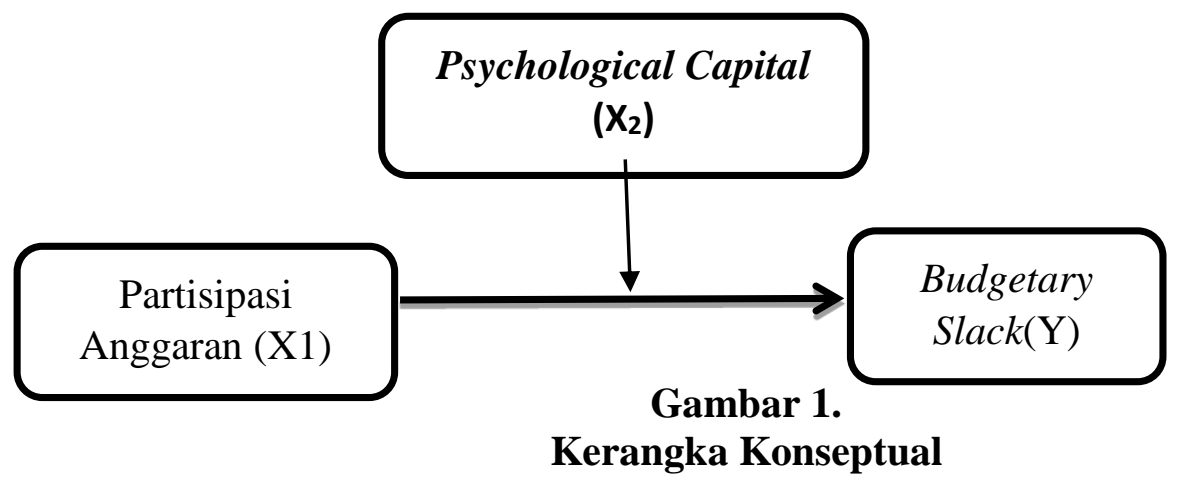

\section{METODE PENELITIAN}

Pada penelitian ini dilakukan di salah satu Perguruan Tinggi dikota Padang yaitu Universtas Bung Hatta yang merupakan universitas terkemuka semenjak tanun 1981 yang terdiri dari 7 fakultas dan 1 program pascasarjana yang terlibat dalam proses penyusunan, pelaksanaan, dan pertanggung jawaban anggaran. Peneliti menguji hipotesis yang ada secarastatistik, data yang diolah akan diproses dari hasil yang akan dijadikan sebagai kerangka jawaban untuk hipotesis 
yang telah ditentukan. Hasil pengujian tersebut kemudian dipaparkan untuk mendukung hipotesis yang telah diajukan. Penelitian ini bertujuan untuk melihat seberapa jauh variabel bebas (variabel independen) mempengaruhi variabel terikat (variabel dependen).

Penelitian ini tergolong penelitian kuantitatif dan mengadopsi penelitian survei sebagai metode untuk mengumpulkan data. Penelitian kuantitatif digunakan untuk membuktikan bahwa teori yang ada dapat diterima atau ditolak. Survei adalah suatu proses pengumpulan dataprimer dari kelompok yang mewakili suatu populasi dengan memberikan berbagai macam pertanyaan kepada responden. Penelitian ini menggunakan skala likert. Skala likert bertujuan untuk mengukur sikap, pendapat, dan persepsi responden tentang fenomenasosial yang terjadi di sekitar mereka. Dalam skala likert, variabel akan dijabarkan menjadi indikator variabel yang kemudia dijadikan titik tolak untuk menyusun item-item yang dapat berupa pernyataan atau pertanyaan. Instrumen penelitian ini dapat berupa cheklist maupun pilihan ganda.

Objek penelitian adalah variabel yang menjadi pusat perhatian dari penelitian. Objek penelitian yang digunakan adalah pejabat struktural di lingkungan bung hatta yang ikut dalam partisipasi yang terlibat didlam menyusunan anggaran. Sampel dalam penelitian ini ditentukan dengan total sampling yang terdiri dari staf akademik maupun non akademik. Sumber data yang digunakan dalam penelitian ini adalah data primer. Data primer berasal dari kuesioner yang disebarkan secara langsung. Dalam penelitian ini data yang diperoleh berasal dari responden di Universitas Bung Hatta..

Penelitian ini merupakan data primer yang berasal dari kuesioner dan wawancara langsung. Data primer yaitu data yang diperoleh secara langsung dari responden melalui penyebaran kuesioner kepada pejabat struktual dilingkungan Universitas Bung Hatta ang terlibat dalam penyusunan anggaran dengan kriteria minimal satu kali ikut dalam penyusunan anggaran (Aditya, 2012). Skala yang digunakan dalam penelitian ini menggunakan skala likeart dengan kateegori skor dilihat dari tabel 1 dibawah ini.

Tabel 1.

Skala Likeart

\begin{tabular}{|c|l|c|c|}
\hline No & Kategori Jawaban & Singkatan & Skor \\
\hline 1 & Sangat Setuju & SS & 5 \\
\hline 2 & Setuju & S & 4 \\
\hline 3 & Netral & N & 3 \\
\hline 4 & Tidak Setuju & TS & 2 \\
\hline 5 & Sangat Tidak Setuju & STS & 1 \\
\hline
\end{tabular}

Variabel dalam penelitian ini menggunakan dua variabel yaitu yang pertama variabel dependen dan yang kedua variabel independen. Variabel independen dalam melakukan penelitian ini adalah partiisipasi annggaran, dimana didefinisikan sebagai kesempatan para baawahan untuk terllibat dalam proses penyusunan anggaran bersama pimpinan Universitas sebagai pusat pertanggungjawaban. Indikator partisipasi anggaran dalam penelitian ini meliputi seberapa besar keterlibatan dalam penyusunan anggaran, tingkat kelogisan alasan atasan untuk merevisi anggaran yang dibuat, intensitas mengajak diskusi tentang anggaran.

Variabel dependen dalam penelitian ini adalah budgetaary slack. yaitu suatu tindakan dimana agen melebihkan kemampuan produktif dengan mengestimasikan pendapatan lebih rendah dan biaya lebih tinggi ketika diberi kesempatan untuk memilih standar kerja. Untuk 
mengukur senjangan anggaran digunakan instrumen yang dikembangkan Dunk (1993), dalam mengukur item-item tersebut digunakan skala interval dengan teknik penilaian skala likert, dimana skor terendah (point 1) menunjukkan jawaban sangat tidak setuju, sedangkan skor tertinggi (point5) menunjukkan jawaban sangat setuju.

Variabel pemoderasi dalam penelitian ini adalah psychological capital. Sebagai keadaan perkembangan psikologi positif individu kompenan psychological capital sendiri terdiri dari empat aspek yaitu self efficacy, optimism, hope dan resiliency yang terdiri dari dua puluh empat butir pertanyaan dengan indikator yaitu kemampuan menemukan solusi bagi masalah yang bersifat jangka panjang, kemampuan melihat sisi baik dari suatu pekerjaan, kemampuan untuk memiliki alternatif dan menyelesaikan suatu masalah. Keseluruhan variabel ini diukur dengan menggunakan skala likert 1 sampai 10, dimana nilai atau skor (1) sama sekali tidak setuju sampai dengan nilai (0) sangay setuju sekali. Metode analisis data menggunakan SPSS 16.0.

\section{Pengembangan Kuesioner}

Kuesioner dalam penelitian ini terdiri dari beberapa pertanyaan yang nantinya akan dipilih respondeen terhadap pertanyaan yang telah diberikan dengan poin satu sampai lima. Poin pertama menunjukkan bahwa responden sangat tidak setuju, poin kedua responden tidak setuju, poin ketiga responden netral, poin keempat responden setuju, dan poin kelima respeonden sangat setuju. Penelitian ini mengenai faktor personal yang ada di dalam diri indiividu. Penelitian ini menggunakan replikasi kuesioner dari penelitian yang telah dilakukan sebelumnya oleh Yuni astuti (2018). Rata-rata skor tingkat capaian responden variabel psychological capital sebesar 79,1\% pada kategori cukup baik. Artinya, kompetensi yang dimiliki individu sudah cukup baik.

\section{Pengujian Instrumen \\ Uji Validitas dan Reliabilitas}

Validitas adalah ketepatan dalam mengukur suatu instrumen (Priyatno, 2010:90). Uji validitas bertujuan untuk memperlihatkan sejauh mana kebenaran data yang didapat dari kuesioner. Validitas dari masing-masing pertanyaan dapat dilihat dari hasil output SPSS pada tabel yang berjudul corrected item-total correlation. Suatu pertanyaan dapat dikatakan valid jika nilai corrected item-total corelation $>\mathrm{r}_{\text {tabel. }}$. Nilai $\mathrm{r}_{\text {tabel }}$ didapatkan dari $\mathrm{df}$ (degree of freedom) $=\mathrm{n}-2$ (Nugroho, 2005:68-72).

Reliabilitas adalah ukuran suatu kestabilan dan konsistensi dari responden dalam menjawab hal yang berkaitan dengan pertanyaan-pertanyaan tentang variabel dan disusun dalam bentuk kuesioner. Untuk melakukan uji reliabilitas dapat dilihat dengan output SPSS yaitu dengan melihat nilai Cronbach's Alpha > dari 0,60 (Nugroho, 2005:72)

\section{Statistika Deskriptif}

Statistika deskriptif digunakan untuk menggambarkan karakteristik pada masing-masing variabel penelitian. Rumus yang dipakai untuk mendapatkan rata-rata skor pada masing-masing indikator dalam pertanyaan kuesioner adalah sebagai berikut:

$$
\text { Rata-rata Skor }=\frac{\sum f i x W o}{\sum f}
$$

Dimana: $\sum f i=$ Total Frekuensi ke i

Wo $=$ Bobot

$\Sigma f=$ Total Frekuensi 
Untuk mendapatkan tingkat capaian jawaban pada responden menggunakan rumus TCR (tingkat pencapaian jawaban responden) (Arikunto, 2002). Rumus TCR adalah sebagai berikut:

$\mathrm{TCR}=\frac{\text { Rata-rata Skor }}{5} \times 100 \%$

\section{Uji Asumsi Klasik dan Normalitas}

Uji normalitas bertujuan untuk menguji apakah data yang didistribusikan mendekati normal. Pada penelitian ini pengujian normalitas menggunakan metode kolmogrov-smirnov dengan angka signifikan 0,05. Jika nilai signifikan yang dihasilkan > 0,05 maka data berdistribusi normal. Uji multikolinieritas dilakukan dengan membandingkan nilai tolerance dan variances inflation factor (VIF). Kedua ukuran tersebut menunjukan setiap variabel independen manakah yang dijelaskan oleh variabel independen yang lain. Jika nilai tolerance lebih besar dari 0,1 dan nilai VIF lebih kecil dari 10, maka tidak terjadi multikolinieritas. Uji Heteroskedastisitas ini digunakan untuk mengetahui apakah dalam suatu model regresi terjadi ketidaksamaan varian dari residual dalam suatu pengamatan kepengamatan yang lain, jika varian dari residual dalam satu pengamatan kepengamatan yang lain tetap maka disebut homoskedastisitas

\section{HASIL DAN PEMBAHASAN \\ Data Demografi Responden}

Data diperoleh dengan memberikan kuesioner pada responden. Jumlah kuesioner yang disebarkan adalah 50 lembar. Berdasarkan hasil pengumpulan data menunjukkan bahwa kuesioner yang kembali dan layak untuk dianalisis sebanyak 40 kuesioner. Pengambilan yang terlihat pada tabel 3 berikut ini.

\section{Tabel 2.}

Tingkat Pengembalian Kuisioner

\begin{tabular}{|l|c|c|}
\hline Responden & Total & $(\mathbf{\% )}$ \\
\hline Kuisioner yang dikirim & 52 & 100 \\
Kuisioner yang tidak kembali/hilang & 12 & 23,07 \\
Kuisioner yang kembali & 40 & 76.93 \\
Kuisioner yang gugur (tidak lengkap) & 0 & 0 \\
Kuisiner yang digunakan & 40 & 76,93 \\
\hline
\end{tabular}

Sumber: Hasil Pengolahan Kuesioner

Tabel 2 menunjukkan bahwa dari 52 kuesioner yang disebar ternyata mendapat respon dari respondennya hanya 40 kuesioner, adanya 12 kuesioner yang tidak kembali dikarenakan hilang dan tidak diisi. Tingkat pengembalian kuesioner pada penelitian ini adalah 23,07\%, sedangkan tingkat pengembalian kuesioner yang dapat digunakan adalah sebesar $76,93 \%$. Pada Tabel 3 kriteria responden yang dapat dijadikan sampel dalam penelitian ini adalah pejabat yang ada di lingkungan Universitas Bung Hatta yang terlibat dalam penyusuanna anggaram. Data demografi menyajikan informasi umum mengenai kondisi responden yang dapat dianalisis secara kualitatif berdasarkan jenis kelamin, usia, pendidikan terakhir dan jabatan. Data demografi responden secara lebih jelas disajikan dalam tabel berikut ini: 
Analisis Data Deskriptif Partisipasi Anggaran, Budgetary Slack dan Psychological Capital Pada bagian ini akan dilihat deskriptif statistik dari hasil kuesioner, dimana dari deskriptif statistik dapat dilihat gambaran umum dari data yang digunakan dalam analisis dan pengujian hipotesa, hasil selengkapnya dapat dilihat dalam tabel 5.

\section{Pengujian Hipotesis}

Hipotesis Pertama (Pengaruh Partisipasi Anggaran terhadap Budgetary Slack

Hasil pengujian regresi I dengan partisipasi anggaran sebagai variabel dependen dan budgetary slack sebagai variabel independen. Hasil pengujian nya dapat dilihat pada tabel 5.

Tabel 3.

Tingkat Pengembalian Kuisioner

\begin{tabular}{|c|c|c|c|c|}
\hline No & $\begin{array}{c}\text { Deskripsi } \\
\text { Karateristik } \\
\text { Responden }\end{array}$ & Kategori & Jumlah (n) & $(\%)$ \\
\hline \multirow{2}{*}{1} & \multirow{2}{*}{ Jenis kelamin } & Laki-laki & 29 & 72,5 \\
\hline & & Perempuan & 11 & 27,5 \\
\hline \multicolumn{3}{|c|}{ Jumlah } & 40 & 100 \\
\hline \multirow{4}{*}{2} & \multirow{4}{*}{ Usia } & 26 - 35 tahun & 1 & 2,5 \\
\hline & & $36-45$ tahun & 14 & 35 \\
\hline & & 46 - 55 tahun & 23 & 57,5 \\
\hline & & $56-65$ tahun & 2 & 5 \\
\hline \multicolumn{3}{|c|}{ Jumlah } & 40 & 100 \\
\hline \multirow{4}{*}{3} & \multirow{4}{*}{$\begin{array}{l}\text { Pendidikan } \\
\text { terakhir }\end{array}$} & D3 & 1 & 2,5 \\
\hline & & S1 & 5 & 12,5 \\
\hline & & S2 & 27 & 67,5 \\
\hline & & S3 & 7 & 17,5 \\
\hline \multicolumn{3}{|c|}{ Jumlah } & 40 & 100 \\
\hline \multirow{4}{*}{4} & \multirow{4}{*}{ Jabatan } & $\begin{array}{l}\text { Pejabat struktural } \\
\text { tingkat universitas }\end{array}$ & 9 & 22,5 \\
\hline & & $\begin{array}{l}\text { Pejabat struktural } \\
\text { tingkat fakultas }\end{array}$ & 14 & 35 \\
\hline & & $\begin{array}{l}\text { Pejabat struktural } \\
\text { tingkat unit }\end{array}$ & 8 & 20 \\
\hline & & $\begin{array}{l}\text { Tim Perumus dan } \\
\text { tim anggaran }\end{array}$ & 9 & 22,5 \\
\hline \multicolumn{3}{|c|}{ Jumlah } & 40 & 100 \\
\hline
\end{tabular}

Sumber: Hasil Pengolahan Kuesioner

Tabel 4.

Deskriptif Data Statistik

\begin{tabular}{|l|r|r|r|r|r|}
\hline & $\mathrm{N}$ & Minimum & Maximum & Mean & Std. Deviation \\
\hline Partisipasi Anggaran & 40 & 12 & 31 & 23.12 & 5.464 \\
\hline
\end{tabular}




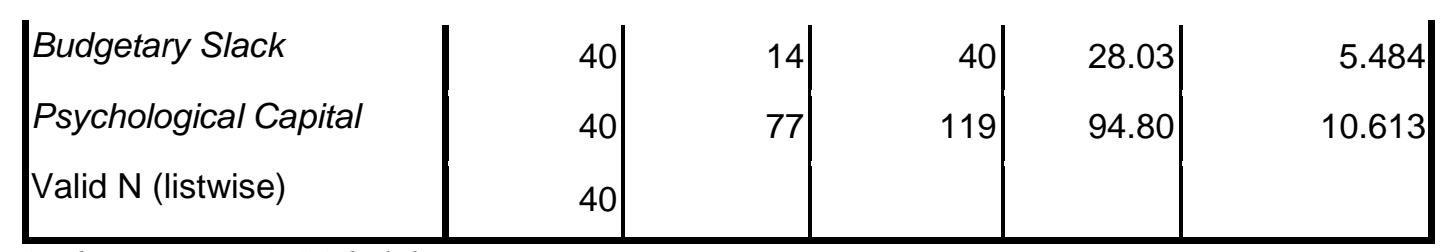

Sumber : Output SPSS diolah

Tabel 5.

Hasil Model Regresi I

\begin{tabular}{|l|r|r|r|r|r|}
\hline Model & $\mathrm{R}$ & R Square & \multicolumn{1}{|c|}{$\begin{array}{c}\text { Adjusted R } \\
\text { Square }\end{array}$} & $\begin{array}{c}\text { Std. Error of } \\
\text { the Estimate }\end{array}$ & $\begin{array}{c}\text { Durbin- } \\
\text { Watson }\end{array}$ \\
\hline 1 & $.830^{\mathrm{a}}$ & .689 & .663 & 9.708 & 1.415 \\
\hline
\end{tabular}

Sumber : Output SPSS diolah

\section{Hipotesis Kedua (Pengaruh Partisipasi Anggaran terhadap Budgetary Slack dengan Psychological Capital Sebagai Variabel Moderasi)}

Hasil pengujian regresi II dengan partisipasi anggaran sebagai variabel dependen dan budgetary slack sebagai variabel independen serta psychological capital sebagai pemoderasi disajikan pada tabel berikut.

Tabel 6.

Hasil Model Regresi II

\begin{tabular}{|l|r|r|r|r|r|}
\hline Model & $\mathrm{R}$ & $\mathrm{R}$ Square & $\begin{array}{l}\text { Adjusted R } \\
\text { Square }\end{array}$ & $\begin{array}{c}\text { Std. Error of } \\
\text { the Estimate }\end{array}$ & Durbin-Watson \\
\hline 1 & $.860^{\mathrm{a}}$ & .740 & .741 & 9.838 & 1.416 \\
\hline
\end{tabular}

Sumber : Output SPSS diolah

\section{Pembahasan}

Hipotesis pertama Berdasarkan hasil uji validitas dan reliabilitasterlihat bahwa instrumen yang digunakan telahvalid dan reliabel. Berdasarkan hasil uji asumsi klasik,terlihat bahwa semua data berdistribusi normalserta model regresi terbebas dari multikolinearitas dan heteroskedastisitas. hasil analisis regresi I menunjukan partisipasi anggaran $t_{\text {hitung }}>t_{\text {tabel }}$ yaitu $(2,934>1,684)$ pada taraf signifikan $<0,05$ yaitu $(0,05<0,006)$ dan koefisien regresi sebesar 0,835 . Hal ini berarti bahwa partisipasi anggaran mempunyai pengaruh positif dan signifikan terhadap budgetary slack. Persamaan regresi sebagai berikut : $\mathrm{Y}=75,496+0,835 \mathrm{X}_{1}$. Nilai $0,835 \mathrm{X}$ disebut juga slope yang menentukan arah regresi linier..

Hipotesis kedua menunjukkan dengan partisipasi anggaran sebagai variabel dependen dan budgetari slack sebagai variabel independen serta psychological capital sebagai pemoderasi menunjukan nilai thitung partisipasi anggaran adalah sebesar 2,871 pada tabel 1,684 dan signifikan 0,007. Psychological capital menunjukan nilai $t_{\text {hitung }} 3,316$ pada tabel 1,684 dan signifikan 0,017. Partisipasi anggaran*psychological capital menunjukan nilai thitung 4,832 pada tabel 1,684 dan signifikan 0,035. Hal ini berarti bahwa variabel psychological capital merupakan pemoderasi dalam hubungan antara partisipasi anggaran dengan budgetary slack. Artinya, psychological capital berperan besar dalam menentukan keberhasilan yang dicirikan oleh adanyakepercayaan diri (self efficacy) 


\section{SIMPULAN, KETERBATASAN, DAN SARAN \\ Kesimpulan}

Berdasarkan hasil penelitian dan pengujian hipotesis yang telah diuraikan sebelumnya, maka dapat diambil kesimpulan sebagai partisipasi anggaran berpengaruh positif signifikan terhadap budgetary slack. DanPsychological capitalyang merupakan pemoderasi dalam hubungan antara partisipasi anggaran dengan budgetary slackdengan melihat tarif signifikansinya terpengaruh secara positif sehingga dapat meninkatkan kinerja yang baik didalam proses penyunan anggaran maupun prakteknya.

\section{Keterbatasan Penelitian}

Metode yang digunakan dalam pengambilan sampel adalah melalui kuesioner sehingga kesimpulan hanya diambil berdasarkan data yang telah diambil melalui penggunaan instrumen secara tertulis.Persepsi bahasa pertanyaan atau pernyataan membuat ekspektasi responden kemungkinan besar diisi sesuai dengan kondisi posisi jabatan yang diemban.Penelitian ini hanya menggunakan kuesioner dalam pengambilan data. Adanya responden yang mencontek atau meniru jawaban dari responden lainnya.

\section{Saran}

Berdasarkan hasil penelitian dan beberapa keterbatasan dalam penelitian ini, peneliti menyarankan hal-hal sebagai berikut:

1. Tingkat capaian responden dengan nilai rendah pada variabel partisipasi anggaran terdapat pada pertanyaan kedua yaitu: saya sering diminta berpendapat dalam penyusunan anggaran dengan TCR $62 \%$ pada kategori kurang baik. Sebaiknya penyusunan anggaran dikerjakan oleh orang yang benar-benar paham dan mengerti sehingga pada saat diminta pendapat mereka bisa mengutarakan maksud dan tujuannya.

2. Tingkat capaian responden dengan nilai rendah pada variabel budgetary slack terdapat pada pertanyaan ketujuh dan kedelapan yaitu: target anggaran yang harus dicapai dan sasaran yang dijabarkan dalam anggaran sangat susah untuk dicapai/ direalisasikan dengan tingkat capaian responden yang sama yaitu $57 \%$ pada kategori kurang baik.

3. Tingkat capaian responden dengan nilai rendah pada pertanyaan pertama yaitu: mampu menemukan solusi bagi masalah yang bersifat jangka panjang dengan tingkat capaian responden $63 \%$ pada kategori kurang baik. Dalam hal ini instansi/ organisasi perlu mengetahui kelemahan-kelemahan dalam organisasi, karena setelah rencana yang baik disusun dan kemudian dijalankan, maka kelemahan-kelemahan dapat dilihat untuk diperbaiki.

4. Untuk penelitian selanjutnya perlu mempertimbangkan variabel moderasilain yang mempengaruhi partisipasi anggaran terhadap budgetary slack.

5. Diharapkan penelitian selanjutnya, dapat melakukan wawancara secara langsung terhadap responden agar data yang diperoleh lebih jelas dan lebih baik.

\section{DAFTAR PUSTAKA}

Abineri, F. (2016). Pengaruh Partisipasi Penyusunan Anggaran terhadap Kinerja Aparat Pemerintah Daerah: Psychological Capital dan Komitmen Organisasi sebagai Variabel Pemoderasi. Jurnal. 
Adikusuma, M. (2017). Analisis Pengaruh Partisipasi Anggaran terhadap Budgetary Slack dengan Kapasitas Individu, Komitmen Organisasi, Locus Of Control sebagai Variabel Moderasi. Jurnal.

Amriyetti, I. (2017). Peran Psychological Capital Memediasi Hubungan Antara Partisipasi Anggaran dari Kinerja Manajerial: Keadilan Prosedual Sebagai Variabel Pemoderasi. Skripsi.

Antony, R.N. dan Govindarajan, V. (2005). Management Control System. Edisi 11. Mc. Grawhill.

Dunk, A. S. (1993). Budgetary Participation, Agreement on evaluation criteria and Managerial Performance, A Research Note. Accounting Organization and Society.

Falikhatun. (2007). Interaksi informasi asimetri, budaya organisasi dan group cohesiveness dalam hubungan antara partisipasi penganggaran dan budgetary slack. Simposium Nasional Akuntansi X.

Ghozali, I. (2014). Structural Equation Modeling: Metode Alternatif Dengan Partial Least Square (PLS) (Vol. 4). Universitas Diponegoro

Ikhsan, A. dan Ane, L. (2007). Pengaruh Partisipasi Anggaran Terhadap Senjangan Anggaran Dengan Menggunakan Lima Variabel Pemoderasi. Proceeding. Simposium Nasional Akuntansi X Universitas Hasanuddin Makasar.

Lina. (2015). Partisipasi Penyusunan Anggaran, Psychological Capital, dan Kinerja Manajerial. Jurnal.

Maya. (2012). Pengaruh Partisipasi Anggran Terhadap Budgetary Slack dengan Pertimbangan Etika Sebagai Variabel Moderasi (Studi Empiris Pada SKPD Kulon Progo). Skripsi. Universitas N0egeri Yogyakarta.

Miyati. (2014). Pengaruh Partisipasi Anggaran terhadap Budgetary Slack dengan Pertimbangan Etika Sebagai Variabel Moderasi. Skripsi. Fakultas Ekonomi Universitas Yogyakarta.

Mulyadi. (2003). Akuntansi Manajemen, Konsep Manfaat dan Rekayasa. Yogyakarta: BP STIE YKPN

Ngadiman dan Nurainun, B. (2014). Partisipasi Anggaran dan Kinerja Manajerial melalui Psychological Capital dan Persepsiterhadap Inovasi. Jurnal Akuntansi.

Nuryani, Y. (2018). Pengaruh Partisipasi Anggaran terhadap Budgetary Slack dengan Psychological Capital Sebagai Variabel Intervening Studi Empiris Pada Rrumah Sakit di Kota Jayapura. Jurnal.

Priliandani, N. M. I. R. dan Yulianto, A. S. (2014). Pengaruh Mediasi Modal Psikologi Pada Hubungan Perencanaan Anggaran Dan Kinerja Pegawai (Studi Empiris Pada PNS Pemerintah Provinsi Banten). Jurnal Akuntansi, 18, 188-201.

Priyetno, A. (2017). Pengaruh Partisipasi Anggaran terhadap Budgetary Slack dengan Gaya Kepemimpinan dan Pertimbangan Etika sebagai Variabel Moderasi. Jurnal.

Tanaya, I. L., \& Krisnadewi, K. A. (2016). Pengaruh Partisipasi Penganggaran Pada Kesenjangan Anggaran Dengan Karakter Personal Sebagai Pemoderasi. E-Jurnal Akuntansi Universitas Udayana, 2061-2090.

Tresnayani, L. G., \& Gayatri. (2016). Pengaruh Partisipasi Anggaran, Asimetri Informasi, Kapasitas Individu dan Kejelasan Sasaran Anggaran Terhadap Potensi Terjadinya Budgetary Slack. E- Jurnal Akuntansi Universitas Udayana,

Venkatessh, R., \& Blaskovich, J. (2012). The Mediating Effect of Psychological Capital On the Budget Participation-Job Performance Relationship. Journal. 
Veronica, A. (2016). Pengaruh Partisipasi Penganggaran, Penekanan Anggaran, Komitmen Organisasi, dan Kompleksitas Tugas terhadap Slack Anggaran pada Bank.

Yunas, Y. (2013). Pengaruh Partisipasi Anggaran terhadap Senjangan Anggaran dengan Gaya Kepemimpinan dan Komitmen Organisasi sebagai Variabel Pemoderasi. Skripsi. Universitas Bung Hatta. 